JURNAL NOMINAL / VOLUME IV NOMOR 2 / TAHUN 2015

\title{
PENGARUH PARTISIPASI PENYUSUNAN ANGGARAN TERHADAP KINERJA \\ MANAJERIAL DENGAN JOB RELEVANT INFORMATION SEBAGAI VARIABEL \\ MODERATING (Studi Pada Dinas Pemerintah Kota Yogyakarta)
}

\author{
Gita Pramudya Saraswati \\ Akuntansi Universitas Negeri Yogyakarta \\ Gita.saraswati@yahoo.com \\ Mimin Nur Aisyah, M.Sc., Ak \\ Staf Pengajar Jurusan Pendidikan Akuntansi Universitas Negeri Yogyakarta
}

\begin{abstract}
Abstrak: Pengaruh Partisipasi Penyusunan Anggaran terhadap Kinerja Manajerial dengan Job Relevant Information sebagai Variabel Moderating (Studi pada Dinas Pemerintah Kota Yogyakarta). Penelitian ini merupakan penelitian kuantitatif yang menggunakan pendekatan kontingensi dengan variabel moderating. Penelitian ini bertujuan untuk mengetahui pengaruh partisipasi penyusunan anggaran terhadap kinerja manajerial serta untuk mengetahui apakah job relevant information memperkuat hubungan antara partisipasi penyusunan anggaran dengan kinerja manajerial. Metode pengumpulan data yang digunakan dalam penelitian ini adalah survei menggunakan kuesioner. Penelitian ini bersifat populatif dengan jumlah responden sebanyak 155 orang manajer pada dinas pemerintah Kota Yogyakarta. Teknik analisis data dalam penelitian ini menggunakan Moderating Regression Analysis (MRA). Hasil penelitian menunjukkan bahwa partisipasi penyusunan anggaran berpengaruh positif dan signifikan terhadap kinerja manajerial. Hal ini terbukti dari hasil regresi yaitu nilai koefisien regresi sebesar 2.037 dan nilai $t_{\text {hitung }}>t_{\text {tabel }}$ sebesar $7.321>1.975$. Berdasarkan kriteria variabel moderating dari hasil MRA, job relevant information dalam penelitian ini bukan merupakan variabel moderating karena nilai koefisien partisipasi penyusunan anggaran 1,577 dengan signifikansi 0,282. Variabel job relevant information memberikan nilai koefisien 0,885 dengan signifikansi 0,308. Variabel moderating $\mathrm{M}$ (interaksi antara Partisipasi dan Job Relevant Information) memberikan nilai koefisien 0,002 dengan signifikansi 0,972.
\end{abstract}

Kata kunci: Kinerja Manajerial, Job Relevant Information, Partisipasi Penyusunan Anggaran.

Abstract: The Effect of Budgetary Participation toward Managerial Performance with Job Relevant Information as Moderating Variable (Study in The Government Agency of Yogyakarta Municipal). This study is a quantitative research using contingency approach with moderating variable. This study is aimed to examine: (1)the effect of budgetary participation toward managerial performance and (2) whether job relevant information is able to strengthen the relationship between budgeting participation and managerial performance. Data collection methods in this study is a survey using questionnaire distribution. It involves the whole population with a number of 155 managers in government agency of Yogyakarta Municipal. The $d$ was analyzed by Moderating Regression Analysis (MRA). The results showed that budgetary participation positively influences managerial performance. It was proved by regression coefficient 2,037 and value of $t_{\text {count }}(7,321)>$ $t_{\text {table }}(1,975)$. In this study, job relevant information is not a moderating variable because budgetary participation coefficient value is 1,577 with significane 0,282. M moderating variable (interaction between budgeting participation and managerial performance) give coefficient value 0,002 with significant 0,972.

Keywords: Managerial Performance, Job Relevant Information, Budgetary Participation 


\section{JURNAL NOMINAL / VOLUME IV NOMOR 2 / TAHUN 2015}

PENDAHULUAN

Anggaran digunakan sebagai pedoman kerja sehingga proses penyusunannya memerlukan organisasi anggaran yang baik, pendekatan yang tepat, serta model-model perhitungan besaran (simulasi) anggaran yang mampu meningkatkan kinerja pada seluruh jajaran manajemen dalam organisasi. Proses penyusunan anggaran, dapat dilakukan dengan beberapa pendekatan yaitu topdown, bottom up dan partisipasi (Ramadhani dan Nasution, 2009).

Dalam sistem penganggaran topdown, dimana rencana dan jumlah anggaran telah ditetapkan sehingga atasan/pemegang kuasa anggaran kurang mengetahui potensi dan hambatan yang dimiliki oleh bawahan/pelaksana anggaran sehingga memberikan target yang sangat menuntut dibandingkan dengan kemampuan bawahan/pelaksana anggaran. Oleh karena itu, entitas mulai menerapkan sistem penganggaran yang dapat menanggulangi masalah di atas yakni sistem penganggaran partisipatif (participative budgeting). Melalui sistem ini, bawahan/pelaksana anggaran dilibatkan dalam penyusunan anggaran yang menyangkut subbagiannya sehingga tercapai kesepakatan antara atasan/pemegang kuasa anggaran dan bawahan/pelaksana anggaran mengenai anggaran tersebut (Omposunggu dan Bawono, 2007).

Partisipasi penganggaran adalah proses yang menggambarkan individuindividu yang terlibat dalam penyusunan anggaran dan mempunyai pengaruh terhadap target anggaran. Partisipasi penyusunan anggaran merupakan pendekatan yang secara umum dapat meningkatkan kinerja yang pada akhirnya dapat meningkatkan efektivitas organisasi (Nor, 2007). Penyusunan anggaran secara partisipatif diharapkan dapat meningkatkan kinerja manajer, yaitu ketika suatu tujuan dirancang dan secara partisipasi disetujui maka karyawan akan menginternalisasikan tujuan yang ditetapkan dan memiliki rasa tanggung jawab pribadi untuk mencapainya, karena mereka ikut terlibat dalam penyusunan anggaran (Milani, 1975).

Manajer yang baik adalah manajer yang menjalankan fungsi-fungsi manajemen dengan efektif. Fungsi-fungsi manajemen tersebut meliputi perencanaan, investigasi, pengkoordinasian, evaluasi, pengawasan, pemilihan staf, negosiasi, dan perwakilan (Mahoney, et al.) dalam Handoko (1996:34). Fungsi-fungsi manajemen ini merupakan indikator untuk mengukur kinerja manajerial. Kinerja manajerial merupakan salah satu faktor yang dapat dipakai untuk meningkatkan efektivitas 


\section{JURNAL NOMINAL / VOLUME IV NOMOR 2 / TAHUN 2015}

organisasi (Sumadiyah dan Susanta, 2004).

Banyak penelitian di bidang akuntansi manajemen yang memperhatikan masalah partisipasi penyusunan anggaran. Hasil-hasil penelitian belum konsisten dan sering terjadi kontradiksi. Penelitian Brownell \& Mc Innes (1986) menemukan bahwa terdapat hubungan positif dan signifikan antara partisipasi dalam penyusunan anggaran dan kinerja manajerial. Milani (1975) dan Brownell \& Hirst (1986) menemukan bahwa partisipasi penyusunan anggaran tidak berpengaruh secara signifikan terhadap kinerja manajerial. Para peneliti menyimpulkan bahwa tidak ada hubungan langsung antara partisipasi penyusunan anggaran dan kinerja manajerial (Gul dkk, (1995) dalam Nanda Hapsari (2010)).

Penelitian terdahulu banyak yang menghubungkan partisipasi penyusunan anggaran dengan kinerja manajerial secara tidak langsung (faktor kontingensi) misalnya menggunakan komitmen tujuan, kultur organisasi, komitmen tujuan, locus of control dan sebagainya. Faktor kontingensi yang digunakan dalam penelitian ini adalah Job Relevant Information (JRI) sebagai variabel moderating karena dianggap dapat memperkuat hubungan antara partisipasi anggaran dan kinerja manajerial.
Baiman (1982) dalam Kren (1992) mengidentifikasi dua jenis informasi utama dalam organisasi yaitu decision influencing dan job relevant information (JRI), yakni informasi yang memfasilitasi pembuatan keputusan yang berhubungan dengan tugas. Baiman (1982) dalam Yusfaningrum dan Ghozali (2005) menambahkan bahwa JRI membantu bawahan/pelaksana anggaran dalam meningkatkan pilihan tindakannya melalui informasi usaha yang berhasil dengan baik. Kondisi ini memberikan pemahaman yang lebih baik pada bawahan mengenai alternatif keputusan dan tindakan yang perlu dilakukan dalam mencapai

tujuan.

Apabila dalam perusahaan terdapat informasi yang memfasilitasi pembuatan keputusan yang berhubungan dengan tugas atau job relevant information (JRI) maka manajer yang terlibat dalam pembuatan anggaran akan menyusun target anggaran dengan baik. Dengan adanya job relevant information (JRI) manajer tidak akan melakukan pembiasan target anggaran guna mencapai target anggaran dengan mudah namun manajer akan berusaha mencapai target anggaran yang telah ditetapkan sebab job relevant information (JRI) yang ada akan memberikan informasi-informasi bagaimana mencapai target anggaran 


\section{JURNAL NOMINAL / VOLUME IV NOMOR 2 / TAHUN 2015}

dengan efektif dan efisien. Usaha untuk mencapai target anggaran tersebut akan mengakibatkan meningkatnya kinerja manajer.

Organisasi pemerintah daerah merupakan organisasi yang bergerak dalam bidang pelayanan publik. Oleh karena itu, kepercayaan yang diberikan oleh masyarakat kepada penyelenggara pemerintah harus diimbangi dengan kinerja yang baik, sehingga pelayanan dapat ditingkatkan secara efektif.

Penyusunan anggaran pada Dinas di Pemerintah Kota Yogyakarta telah menggunakan penganggaran partisipatif. Informasi yang didapat dari Kepala Bagian Keuangan Dinas Perhubungan Kota Yogyakarta, menyebutkan bahwa penyusunan anggaran pada SKPD menggunakan sistem bottom up yang dilaksanakan melalui masukan dari seksi, bidang, sub bagian, sekretariat dan Unit Pelaksana Teknis dengan mempertimbangkan rencana kerja tahunan dan rencana strategis. Penyusunan anggaran juga memperhatikan masukan dari masyarakat melalui Musrenbang (Musyawarah Perencanaan Pembangunan) yang kemudian dibahas dengan Tim Anggaran Pemerintah Kota dan selanjutnya dibahas dengan DPRD Kota Yogyakarta. Peran manajer dalam penyusunan anggaran sebagai pengarah dan penyelia dari usulan-usulan anggaran dengan harapan anggaran dapat mencapai kinerja dan tujuan instansi. Namun, lamanya proses pembahasan anggaran yang disebabkan kurang matangnya perencanaan dapat menyebabkan tertundanya pelaksanaan tugas manajer.

Sekretaris Dinas Ketertiban menjelaskan juga bahwa setiap tingkatan manajemen memiliki tugas pokok dan fungsi (tupoksi) yang berbeda. Walaupun demikian, setiap manajer telah melakukan tugas dan fungsi pokok seorang manajer, yaitu planning, organizing, executing, dan controlling. Hal ini dapat dilihat dari tugas setiap manajer dalam mengkoordinir, menyesuaikan, dan mencermati kegiatan maupun program agar dapat menunjang visi dan misi instansi. Transfer informasi yang terjadi di setiap tingkatan manajemen memberikan gambaran dan pengetahuan agar manajer dapat melaksanakan tugasnya dengan baik.

Menurut seorang staf operasional anggaran Dinas Kesehatan, informasi mengenai kebutuhan pelaksanaan kegiatan dari bawahan/ unit pelaksana terkadang terganjal oleh standar yang telah ditetapkan Pemerintah Kota. 


\section{JURNAL NOMINAL / VOLUME IV NOMOR 2 / TAHUN 2015}

\section{METODE PENELITIAN}

\section{Jenis Penelitian}

Menurut jenis dan analisis datanya, penelitian ini termasuk penelitian sebab akibat (causal study).

\section{Waktu dan Tempat Penelitian}

Penelitian ini dilaksanakan pada 13 dinas di Pemerintah Kota Yogyakarta, dengan responden penelitian manajer tingkat atas, manajer tingkat menengah, dan manajer tingkat bawah yang berpartisipasi dalam penyusunan anggaran. Waktu penelitian dilakukan pada bulan Juni - September 2015.

\section{Target/Subjek Penelitian}

Populasi pada penelitian ini adalah manajer pada dinas di Pemerintah Kota Yogyakarta yang berjumlah 155 orang. Sampel yang digunakan dalam penelitian ini adalah manajer pada dinas di Pemerintah Kota Yogyakarta yang ikut berpartisipasi dalam penyusunan anggaran berjumlah 155 orang.

\section{Prosedur}

Metode pengumpulan data yang digunakan dalam penelitian ini adalah dengan menggunakan metode survey. Data dikumpulkan dengan survei langsung melalui kuesioner yang didesain untuk memperoleh data tentang kinerja manajerial. Partisipasi penyusunan anggaran, dan Job Relevant Information. Data yang digunakan dalam penelitian ini merupakan data primer.

Data, Instrumen, dan Teknik Pengumpulan

Data

Data penelitian ini adalah data primer. Data dikumpulkan dengan survei langsung melalui kuesioner yang didesain untuk memperoleh data tentang kinerja manajerial, partisipasi penyusunan anggaran, dan Job Relevant Information. Instrumen dalam variabel Kinerja Manajerial terdiri dari pertanyaanpertanyaan yang terkait dengan fungsi manajemen dan ditambahkan indikator kinerja secara keseluruhan. Indikator yang digunakan untuk mengukur variabel partisipasi penyusunan anggaran adalah keterlibatan manajer dalam penyusunan anggaran, pengawasan proses penyusunan anggaran, tujuan pelaksanaan anggaran pada bidang yang dipimpin. Pengukuran dalam variabel job relevant information menggunakan kuesioner yang dikembangkan oleh Kren (1992).

\section{Teknik Analisis Data}

Pengambilan data secara primer dilakukan dengan menggunakan kuesioner, maka digunakan pengujian kualitas data dengan uji validitas dan reliabilitas. 
Setelah diperoleh data penelitian, dilakukan uji asumsi klasik yang meliputi uji linieritas, uji multikolinearitas, dan uji heteroskedastisitas. Metode analisis data yang digunakan adalah analisis regresi linier sederhana dan Moderating Regression Analysis (MRA).

\section{HASIL PENELITIAN DAN} PEMBAHASAN

Data yang digunakan adalah data primer hasil kuesioner yang disebarkan kepada manajer Dinas Pemerintah Kota Yogyakarta. Kuesioner yang disebarkan sebanyak 155 buah kuesioner.

Identitas Responden Penelitian

Tabel 1. Deskripsi Data Responden berdasarkan Jenis kelamin

\begin{tabular}{cccc}
\hline No. & Jenis Kelamin & Jumlah & $\mathbf{( \% )}$ \\
\hline 1. & Pria & 76 & 49,03 \\
2. & Wanita & 79 & 50,98 \\
\hline
\end{tabular}

Sumber: Data primer diolah, 2015

Tabel 2. Deskripsi Data Responden berdasarkan Tingkat Pendidikan

\begin{tabular}{cccc}
\hline No. & Tingkat Pendidikan & Jumlah & $\mathbf{( \% )}$ \\
\hline 1. & SLTA & 15 & 9,68 \\
2. & D3 & 22 & 14,19 \\
3. & S1 & 96 & 61,94 \\
4. & S2 & 22 & 14,19 \\
& Jumlah & 155 & 100 \\
\hline
\end{tabular}

Sumber: Data primer diolah, 2015

Tabel 3. Deskripsi Data Responden berdasarkan Umur

\begin{tabular}{cccc}
\hline No. & Usia & Jumlah & $\mathbf{( \% )}$ \\
\hline 1. & $26-30$ tahun & 2 & 1,29 \\
2. & $31-35$ tahun & 10 & 6,45 \\
3. & $36-40$ tahun & 25 & 16,13 \\
4. & $41-45$ tahun & 37 & 23,87 \\
5. & $46-50$ tahun & 33 & 21,29 \\
6. & $>50$ tahun & 48 & 30,97 \\
& Jumlah & 155 & 100 \\
\hline
\end{tabular}

Sumber: Data primer diolah, 2015

Tabel 4. Deskripsi Data Responden berdasarkan Jabatan

\begin{tabular}{llcc}
\hline No. & \multicolumn{1}{c}{ Jabatan } & Jumlah & (\%) \\
\hline 1. & Kepala & 14 & 9,03 \\
& Bidang/Bagian & & \\
2. & Kepala & 35 & 22,5 \\
& SubBagian/Bidang & & 8 \\
3. & Kepala Seksi & 106 & 68,3 \\
& & & 9 \\
& $\quad$ Jumlah & 155 & 100 \\
\hline
\end{tabular}

Sumber: Data primer diolah, 2015

Tabel 5. Deskripsi Data Responden berdasarkan Lama Bekerja

\begin{tabular}{cccc}
\hline No. & $\begin{array}{c}\text { Lama } \\
\text { Bekerja }\end{array}$ & Jumlah & $\mathbf{( \% )}$ \\
\hline 1. & $1-5$ tahun & 11 & 7,1 \\
2. & $6-10$ tahun & 13 & 8,39 \\
3. & $11-15$ tahun & 14 & 9,03 \\
4. & $16-20$ tahun & 56 & 36,13 \\
5. & $>20$ tahun & 61 & 39,35 \\
& Jumlah & 155 & 100 \\
\hline
\end{tabular}

Sumber: Data primer diolah, 2015

\section{Analisis Data}

Uji Linieritas

Tabel 6. Hasil Uji Linearitas

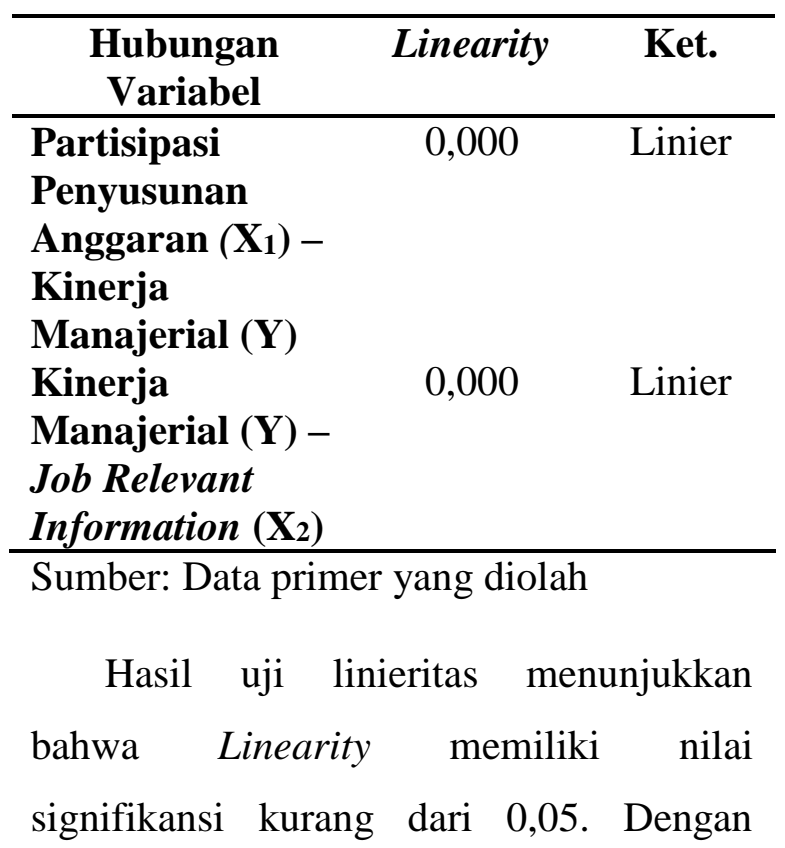




\section{JURNAL NOMINAL / VOLUME IV NOMOR 2 / TAHUN 2015}

demikian, hubungan antara variabel

Partisipasi Penyusunan Anggaran, Kinerja Manajerial terhadap Job Relevant Information adalah linier yaitu semua variabel mempunyai hubungan garis lurus.

\section{Uji Heteroskedastisitas}

Tabel 7. Hasil Uji Heteroskedastisitas

\begin{tabular}{lcl}
\hline \multicolumn{1}{c}{ Variabel } & Sig & \multicolumn{1}{c}{ Kesimpulan } \\
\hline Partisipasi & 0,198 & Tidak terjadi \\
$\begin{array}{l}\text { Penyusunan } \\
\text { Anggaran }\end{array}$ & & Heteroskedastisitas \\
$\begin{array}{l}\text { Job } \\
\text { Relevant }\end{array}$ & 0,125 & $\begin{array}{l}\text { Tidak terjadi } \\
\text { Information }\end{array}$ \\
\hline
\end{tabular}

Sumber: Data primer yang diolah

Nilai signifikansi pada kedua variabel lebih besar dari 0,05 sehingga dapat disimpulkan bahwa tidak terjadi heteroskedastisitas dalam model regresi.

\section{Uji Multikolinearitas}

Tabel 8. Hasil Uji Multikolinearitas

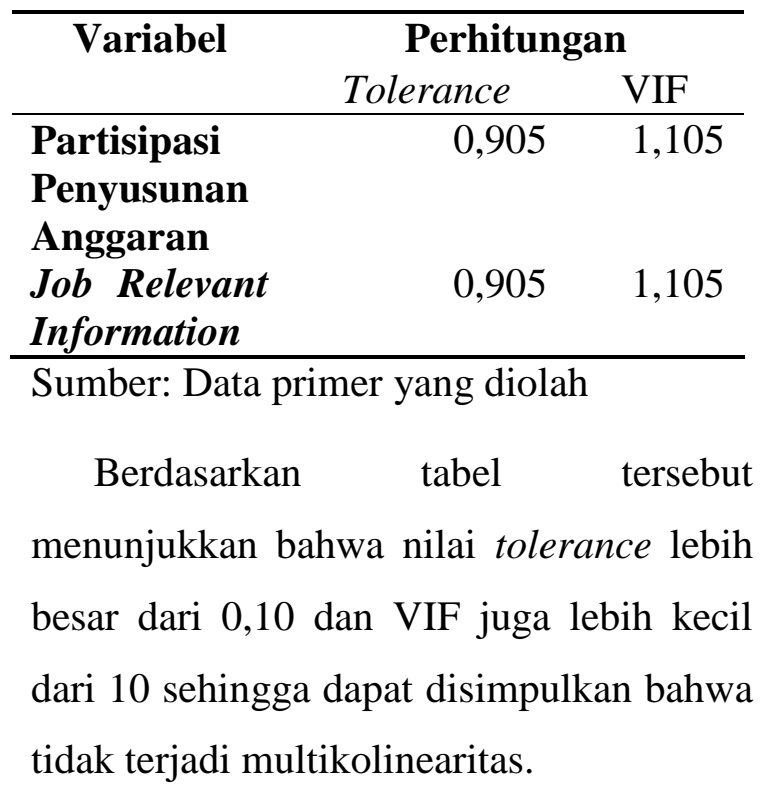

\section{Hasil Uji Hipotesis}

Hipotesis 1, Partisipasi penyusunan anggaran berpengaruh positif terhadap kinerja manajerial.

Tabel 9. Ringkasan Hasil Analisis Regresi Linier Sederhana

\begin{tabular}{llll}
\hline Variabel & $\begin{array}{c}\text { Koefisien } \\
\text { regresi }\end{array}$ & thitung & Sig \\
\hline Konstanta & 20,627 & & \\
Partisipasi & 2,037 & 7,321 & 0,000 \\
Penyusunan & & & \\
Anggaran & & & \\
R : $\mathbf{0 , 5 0 9}$ & & \\
$\boldsymbol{R}$ square : $\mathbf{0 , 2 5 9}$ & \\
\hline \multicolumn{3}{l}{ Sumber: Data primer yang diolah } \\
\end{tabular}

Hasil penelitian mendukung hipotesis pertama bahwa terdapat pengaruh partisipasi penyusunan anggaran terhadap kinerja manajerial. Hal ini ditunjukkan dengan koefisien regresi $\mathrm{X}$ sebesar 2,037 bernilai positif. Hal ini berarti bahwa setiap kenaikan partisipasi penyusunan anggaran sebesar 1 satuan akan menaikkan variabel Kinerja Manajerial sebesar 2,037 satuan. Hal ini berarti bahwa arah model regresi tersebut adalah positif.

Koefisien determinasi $\left(\mathrm{R}^{2}\right)$ Square sebesar 0,259 hal ini menunjukkan 25,9\% Kinerja Manajerial dipengaruhi oleh Partisipasi Penyusunan Anggaran, sedangkan sisanya sebesar $74,1 \%$ dipengaruhi oleh variabel lain di luar penelitian ini.

Hasil analisis regresi linier sederhana antara Partisipasi Penyusunan Anggaran terhadap Kinerja Manajerial diperoleh nilai 


\section{JURNAL NOMINAL / VOLUME IV NOMOR 2 / TAHUN 2015}

$\mathrm{t}_{\text {hitung }}$ sebesar 7,321 dan nilai $\mathrm{t}_{\text {tabel }}$ sebesar 1,975. Hasil ini menunjukkan bahwa $t_{\text {hitung }}$ lebih besar daripada $t_{\text {tabel. }}$. Sedangkan uji $\mathrm{t}$ untuk variabel Partisipasi Penyusunan Anggaran menghasilkan nilai signifikansi 0,000 yang berarti lebih kecil dari nilai 0,05, sehingga dapat disimpulkan bahwa variabel Kinerja Manajerial dipengaruhi oleh variabel Partisipasi Penyusunan Anggaran. Dengan demikian, hipotesis pertama yang menyatakan bahwa Partisipasi Penyusunan Anggaran berpengaruh positif terhadap Kinerja Manajerial diterima.

Hasil penelitian ini mendukung hasil penelitian yang dilakukan oleh Yogi Andrianto (2008) dengan judul "Analisis Pengaruh Partisipasi Penyusunan Anggaran Terhadap Kinerja Manajerial Job Relevant Information sebagai Variabel Moderating." Hasil dari penelitian tersebut menunjukkan Partisipasi Penyusunan Anggaran berpengaruh terhadap Kinerja Manajerial.

Hasil penelitian ini mengindikasikan bahwa terdapat pengaruh positif Partisipasi Penyusunan Anggaran terhadap Kinerja Manajerial. Semakin tinggi keterlibatan manajer dalam Partisipasi Penyusunan Anggaran maka akan meningkatkan Kinerja Manajerial. Partisipasi penyusunan anggaran merupakan keterlibatan para manajer dalam suatu organisasi dalam pencapaian sasaran yang telah ditetapkan dalam anggaran. Dengan adanya partisipasi tersebut akan mendorong para manajer untuk bertanggung jawab terhadap masing-masing tugas yang diembannya sehingga para manajer akan meningkatkan kinerjanya agar mereka dapat mencapai sasaran atau target yang telah ditetapkan dalam anggaran. Hal ini mengindikasikan adanya hubungan yang positif antara Partisipasi Penyusunan Anggaran dengan Kinerja Manajerial. Jadi keterlibatan manajer dalam penyusunan anggaran dapat berpengaruh positif dengan meningkatnya Kinerja Manajerial.

Partisipasi Penyusunan Anggaran mempunyai peran yang cukup besar dan mempunyai pengaruh yang kuat terhadap Kinerja Manajerial. Berdasarkan data yang diperoleh, skor jawaban responden pada Partisipasi Penyusunan Anggaran paling rendah dalam hal pengaruh responden tercermin dalam anggaran final/akhir. Hal tersebut mengindikasikan adanya partisipasi semu (pseudoparticipation) yang disebabkan karena organisasi tidak sungguh-sungguh dalam menerapkan partisipasi. Manajer tingkat bawah terpaksa menyatakan persetujuan terhadap keputusan yang ditetapkan oleh manajemen puncak karena perusahaan memerlukan persetujuan mereka. 


\section{JURNAL NOMINAL / VOLUME IV NOMOR 2 / TAHUN 2015}

Hipotesis 2, Job Relevant Information memperkuat pengaruh partisipasi anggaran terhadap kinerja manajerial.

Tabel 10. Ringkasan Hasil Analisis Regresi Linier Moderasi

\begin{tabular}{llll}
\hline \multicolumn{1}{c}{ Variabel } & $\begin{array}{c}\text { Koefisien } \\
\text { regresi }\end{array}$ & $\mathbf{t}_{\text {hitung }}$ & Sig \\
\hline Konstanta & 0,574 & & \\
$\begin{array}{l}\text { Partisipasi } \\
\text { Penyusunan }\end{array}$ & 1,577 & 1,079 & 0,282 \\
$\begin{array}{l}\text { Anggaran } \\
\text { Job }\end{array}$ & 0,885 & 1.023 & 0,308 \\
$\begin{array}{l}\text { Relevant } \\
\text { Information }\end{array}$ & & & \\
$\begin{array}{l}\text { Interaksi } \\
\text { R square : } \mathbf{0 , 3 5 9}\end{array}$ & 0,002 & 0,035 & 0,972 \\
\hline
\end{tabular}

Dependent variable : Kinerja

Sumber : data primer yang diolah

Berdasarkan tabel tersebut, maka dapat dilihat bahwa Nilai koefisien $\mathrm{X}$ sebesar 1,577 yang berarti Partisipasi Penyusunan Anggaran meningkat 1 poin maka Kinerja Manajerial akan naik sebesar 1,577 satuan dengan asumsi $X_{2}$ dan $X_{1} X_{2}$ tetap. Nilai koefisien $\mathrm{X}_{2}$ sebesar 1,577 yang berarti Job Relevant Information meningkat 1 poin maka Kinerja Manajerial akan naik sebesar 1,577 satuan dengan asumsi $\mathrm{X}_{1}$ dan $\mathrm{X}_{1} \mathrm{X}_{2}$ tetap. Nilai koefisien $\mathrm{X}_{1} \mathrm{X}_{2}$ sebesar 0,002 yang berarti variabel moderasi meningkat 1 poin maka Kinerja Manajerial akan naik sebesar 0,002 satuan dengan asumsi $X_{1}$ dan $X_{2}$ tetap. Hal ini berarti arah model tersebut adalah positif. Hal ini juga dapat dilihat dari nilai korelasi regresi (R) yang bernilai positif antara Partisipasi Penyusunan Anggaran terhadap
Kinerja Manajerial dengan Job Relevant Information sebagai variabel moderasi sebesar 0,599.

Berdasarkan tabel di atas nilai $R$ Square yang diperoleh sebesar 0,359, maka dapat disimpulkan Kinerja Manajerial dipengaruhi oleh variabel Partisipasi Penyusunan Anggaran, dengan Job Relevant Information sebagai variabel moderator sebesar $35,9 \%$ sedangkan sisanya $64,1 \%$ dipengaruhi variabel lain diluar penelitian ini.

Dilihat dari tabel di atas, dapat disimpulkan bahwa Partisipasi Penyusunan Anggaran memberikan nilai koefisien 1,577 dengan signifikansi 0,282. Variabel Job Relevant Information memberikan nilai koefisien 0,885 dengan signifikansi 0,308. Variabel moderating $\mathbf{M}$ (interaksi antara Partisipasi dan Job Relevant Information) memberikan nilai koefisien 0,002 dengan signifikansi 0,972 . Hasil uji t dan uji anova setelah memasukkan variabel interaksi, diketahui bahwa probabilitas signifikansi di atas 0,05, sedangkan variabel interaksi antara Partisipasi dengan Job Relevant Information ternyata juga tidak signifikan. Dengan demikian, dapat disimpulkan bahwa variabel Job Relevant Information dalam penelitian ini bukanlah variabel moderating karena variabel interaksi antara Partisipasi dan Job Relevant Information tidak signifikan. 


\section{JURNAL NOMINAL / VOLUME IV NOMOR 2 / TAHUN 2015}

Hasil penelitian ini mendukung hasil penelitian Yogi Andrianto pada tahun 2008 dengan judul "Analisis Pengaruh Partisipasi Penyusunan Anggaran Terhadap Kinerja Manajerial dengan Kepuasan Kerja, Job Relevant Information dan Kepuasan Kerja sebagai Variabel Moderating (Studi Empiris Pada Rumah Sakit Swasta Di Wilayah Kota Semarang)" menyatakan bahwa Job Relevant Information tidak dapat berperan sebagai variabel moderating. Hal ini berarti Partisipasi Penyusunan Anggaran tidak dapat meningkatkan Kinerja Manajerial jika disertai dengan Job relevant Information. Dengan kata lain, Job relevant information tidak mampu bertindak secara signifikan sebagai variabel moderating yang mempengaruhi hubungan Partisipasi Penyusunan Anggaran dalam meningkatkan Kinerja Manajerial.

Berdasarkan data yang diperoleh, skor jawaban responden pada Kinerja Manajerial paling rendah berada dalam fungsi manajemen pada item negosiasi yaitu dalam melakukan kontrak untuk barang atau jasa yang dibutuhkan pada unit/sub unit dengan pihak luar. Sedangkan skor jawaban responden pada Job Relevant Information yang tersedia paling sedikit yaitu informasi tentang bagian atau fungsi yang berbeda dalam organisasi (bagian lain dalam organisasi).
Hal tersebut dimungkinkan karena kurangnya koordinasi antara kepala bidang dalam organisasi. Sedikitnya informasi mengenai bagian lain dalam organisasi menyebabkan Kinerja Manajerial menjadi kurang maksimal. Informasi tersebut dapat membantu dalam proses penyusunan anggaran, dimana anggaran antara satu bagian akan mempengaruhi anggaran bagian lain.

\section{SIMPULAN DAN SARAN}

\section{Simpulan}

1. Pengujian yang dilakukan memberikan hasil yang mendukung hipoteis 1 , yaitu Partisipasi Penyusunan Anggaran berpengaruh positif terhadap Kinerja Manajerial. Hal ini ditunjukkan dengan Koefisien Regresi X sebesar 2,037 nilai korelasi regresi (r) yang bernilai positif antara Partisipasi Penyusunan Anggaran dan Kinerja Manajerial sebesar 0,509. Berdasarkan hasil analisis data diperoleh nilai thitung 7,321 yang lebih besar dari $t_{\text {tabel }} 1,975$.

2. Pengujian yang dilakukan memberikan hasil bahwa hipotesis 2 tidak dapat didukung artinya Job Relevant Information tidak memperkuat hubungan antara Partisipasi Penyusunan Anggaran dengan Kinerja Manajerial. Hal tersebut ditunjukkan dari hasil pengujian hipotesis 2 sesudah ada interaksi $\mathrm{X}_{1} * \mathrm{X}_{2}$ 
menghasilkan nilai $\beta_{1}=1.577$, dengan nilai statistik $\mathrm{t}=1.079$ dan nilai signifikansi $0.282>0.05$ adalah tidak signifikan. Sedangkan untuk nilai $\beta_{2}=$ 0.885 dengan nilai statistik $\mathrm{t}=1.023$ dan nilai signifikansi 0.308 adalah tidak signifikan. Sementara itu nilai $\beta_{3}$ $=0.002$ dengan nilai statistik $\mathrm{t}=0.035$ dan nilai signifikansi 0.972 adalah tidak signifikan.

\section{Saran}

1. Bagi manajer tingkat atas untuk mempertimbangkan masukan anggaran dari manajer tingkat menengah dan bawah, sehingga diharapkan kinerja manajer dapat meningkat.

2. Bagi para manajer lebih meningkatkan kemampuan negosiasi mereka dalam melakukan kontrak dengan pihak luar. Kegiatan tersebut akan efektif dan efisien karena kebutuhan pada tiap-tiap bagian adalah manajer bagian masingmasing.

3. Bagi para manajer diharapkan lebih meningkatkan lagi koordinasi dengan para manajer di bidang lain, sehingga informasi yang berkaitan dengan tugas mampu membantu manajer dalam pengambilan keputusan saat penyusunan anggaran.

4. Bagi peneliti atau calon peneliti yang lain agar menambah jumlah populasi dan sampel, misalnya memperluas penelitian tidak hanya di dinas pemerintah kota namun juga penelitian di dinas pemerintah provinsi maupun dinas pemerintah daerah pada daerah lain sehingga data yang didapat lebih luas dan dapat membandingkan antara dinas satu dengan dinas yang lain.

\section{DAFTAR PUSTAKA}

Ramadhani dan Nasution. 2009. "Pengaruh partisipasi anggaran terhadap prestasi manajer pusat pertanggungjawaban dengan motivasi sebagai variabel mediating". Jurnal tidak dipublikasikan. Faculty of Economic, University of Sumatra Utara.

Krisler Bornadi Ompusunggu dan Icuk Rangga Bawono. (2006). "Pengaruh Partisipasi Anggaran Dan Job Relevant Information (JRI) Terhadap Informasi Asimetris (Studi pada Badan Layanan Umum Universitas Negeri di Kota Purwokerto Jawa Tengah)." Jurnal Simposium Nasional 9 Padang.

Nor, W. 2007. "Desentralisasi dan Gaya Kepemimpinan Sebagai Variabel Moderating dalam Hubungan Antara Partisipasi Penyusunan Anggaran dan Kinerja". Simposium Nasional Akuntansi X, hal. 1-27.

Milani, Ken. (1975). "The Relationship of Participation in Budget-Setting to Industrial Supervisor Performance and Attitudes: A Field Study". The Accounting Review. Vol. 50, No. 2 April 1975 page 274-284. 
Kren, Leslie. (1992) "Budgetary Participation and Managerial Performance: The Impact of Information and Environmental Volatility" The Accounting Review Vol. 67 No. 3.

Kusnasriyanti Yusfaningrum dan Imam Ghozali. (2006). “Analisis Pengaruh Partisipasi Anggaran Terhadap Kinerja Manajerial Melalui Komitmen Tujuan Anggaran Dan Job Relevant Information (JRI) Sebagai Variabel Intervening (Penelitian Terhadap Perusahaan Manufaktur Di Indonesia).”

T. Hani Handoko. 1996. Manajemen Perencanaan dan Sumber Daya Manusia. Yogyakarta: PT BPFE.

Sumadiyah dan Susanta, Sri. 2004. “Job Relevant Information dan Ketidakpastian Lingkungan dalam Hubungan Partisipasi Penyusunan Anggaran dan Kinerja Manajerial.”
Simposium Nasional Akuntansi VII Bali.

Brownell, P., \& Morris Mc Innes. (1986). "Budgetary Participation, Motivation, and Performance". The Accounting Review, Vol.61, No.4, October 1986 page 587-600.

Brownell, P., \& Mark Hirst. (1986). "Reliance on Accounting Information, Budgetary Participation, and Task Uncertainty: Tests of A Three Way Interaction". The Accounting Review, Vol.24, No.2, 1986.

Nanda Hapsari A.R. (2010). "Pengaruh Partisipasi Penyusunan Anggaran Terhadap Kinerja Manajerial Dengan Komitmen Organisasi Dan Locus Of Control Sebagai Variabel Moderating (Studi Kasus Pada PT Adhi Karya (Persero) Tbk. Divisi Kontruksi I)". Skripsi. Universitas Diponegoro. Semarang. 